\title{
Institutional Reform of Rural Land Circulation: Model Innovation and Government Roles
}

\author{
Bi-Gang HONG ${ }^{1, a, *}$ \\ ${ }^{1}$ Department of Economics \& Management, Shaoyang University, Shaoyang, China \\ ahong6210@126.com \\ ${ }^{*}$ Corresponding author
}

Key words: Rural land, Circulation, Model innovation, Government Role

\begin{abstract}
The change of land system from collective operation to the household contract responsibility system at the beginning of China's reform and opening-up had effectively motivated the enthusiasm of the peasants, which resulted in the rapid agricultural development. However, the urbanization process in recent years has attracted large numbers of migrant workers from the countryside, leading to a large amount of idle land in rural areas. Land circulation of various forms can bring about scale economy and makes for the development of modern agriculture, but under the unprompted land transfer practice based on individual decisions, the rights of the parties concerned can not be fully guaranteed, which is detrimental to the upgrade of agricultural industry. As a consequence, model innovation of land circulation is vital and governments at all levels have a big role to play.
\end{abstract}

\section{Introduction}

Industrialization and urbanization as well are giving rise to more employment and better development space in the urban areas, which attracts larger numbers of young peasants as migrant workers to the second or third industry, where the income from wages and salaries or capital contribute their main source of finance. Comparative profit makes peasants less and less dependent on rural land, so they are more willing to have their land transferred. Meanwhile, some big farming households, specialized cooperatives and leading enterprises are in pressing need of land. From the perspectives of free market system, demand and supply are enough to make it go, but in a surrounding where there is serious information asymmetry, land circulation is hampered. It is the government's role to establish rules to regulate and facilitate land circulation in rural areas. Land is the base of existence for peasants, the foundation of development for agriculture, and the key to success for rural reform. How to further emancipate the rural productive forces by accelerating the circulation of the rural contracted land use rights is vital to the development of rural economy and constitutes the top priority of governments at all levels.

\section{Significance of Rural Land Circulation Reform}

\section{It provides an effective institutional arrangement ensuring the income increase of peasants.}

Theoretically, land circulation in rural areas can lead to income increase of peasants by the following means. First, farming land concentration to big households can make up for the defects of scattered operation and produce scale effect. Second, scale operation facilitates the use of high-tech and application of modern agricultural machines, which reduces cost while promotes economic efficiency. Thirdly, re-allocation of land sources generates big enterprises, specialized cooperatives and big farming households and culturists which will absorb migrant workers released from the 
countryside and increase their non-agricultural income. Fourthly, land transfer can bring them 600-800 yuan capital income per mu per year. The income-increasing mechanism is best illustrated as follows. (See Fig. 1)

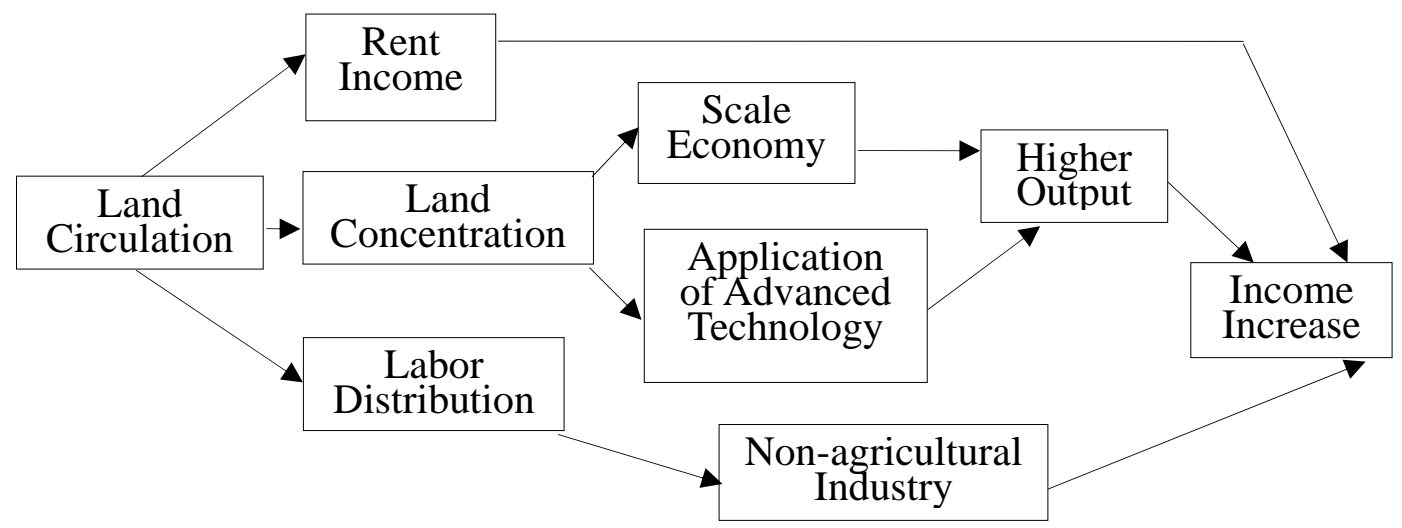

Fig. 1: Income Increase Mechanism Based on Rural Land Circulation

It promotes the structural adjustment of agricultural export commodities and upgrading of the agriculture industry, thus improving our competitive edge in the international market and ensuring food safety.

Our agriculture commodities trade has seen a consecutive increase of five years beginning from 2003, but due to the 2008 financial crisis, our trade decreased in 2009. From 2010 on, things have greatly changed with the total volumes setting new records year after year. In 2012, the total trade volumes of agriculture commodities amounted to $\$ 175.77$ billion. (See Table 1 )

Table 1: Agricultural Commodities Trade Statistics of China (billion dollar)

Sources: Based on International Trade Information Web, CCPIT

\begin{tabular}{|l|l|l|l|l|l|l|l|l|l|l|}
\hline year & 2003 & 2004 & 2005 & 2006 & 2007 & 2008 & 2009 & 2010 & 2011 & 2012 \\
\hline Total & 40.36 & 51.42 & 56.29 & 63.02 & 78.10 & 99.16 & 92.13 & 121.96 & 155.62 & 175.77 \\
\hline Export & 21.43 & 23.39 & 27.58 & 31.03 & 37.01 & 40.50 & 39.59 & 49.41 & 60.75 & 63.29 \\
\hline Import & 18.93 & 28.03 & 28.71 & 31.99 & 41.09 & 58.66 & 52.55 & 72.55 & 94.87 & 112.48 \\
\hline Surplus & 2.50 & -4.64 & -1.13 & -0.96 & -4.08 & -18.16 & -12.96 & -23.14 & -34.12 & -49.19 \\
\hline
\end{tabular}

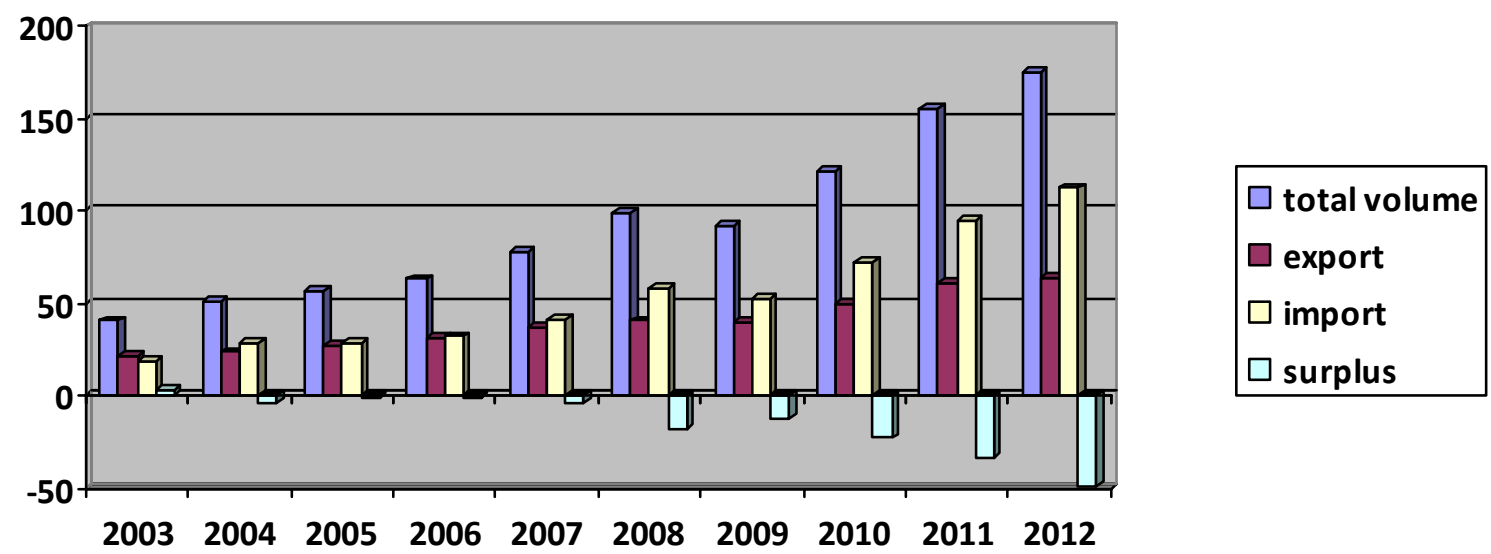

At the same time, we can see that our trade balance has turned from surplus in 2003 to deficit in 2004, and the amount has been increasing, with a $\$ 49.19$ billion trade deficit in 2012.This is partly 
due to unreasonable agricultural commodity structure, and partly to our small-scale operation. Among the export commodities, the ratio of rough-wrought products and highly processed products is 8 to 2. Compared with the developed economies, the gap is prominent. The increasing trade deficit and unreasonable structure of our agricultural commodities hinders the whole economic development and poses a threat to our food safety as well.(See Table 2)

Table 2: Comparison of Food Consumption (thousand tons) and Safety Coefficient Sources: Based on World Bank WDI Data Base

\begin{tabular}{|c|c|c|c|c|}
\hline Country & Food Output & Food Consumption & Food Reserves & $\begin{array}{c}\text { Safety } \\
\text { Coefficient }\end{array}$ \\
\hline Canada & 5364.0 & 1477.780 & 266.00040 & 2.449768978 \\
\hline USA & 44026.4 & 13214.208 & 2378.55744 & 2.151747162 \\
\hline France & 722.6 & 2510.028 & 451.80504 & 1.898292354 \\
\hline Russia & 12621.4 & 5950.104 & 1071.01872 & 0.941206621 \\
\hline Germany & 6136.6 & 3354.372 & 603.78696 & 0.649433348 \\
\hline Brazil & 9984.4 & 7799.740 & 1403.95320 & 0.100093953 \\
\hline China & 63995.2 & 54835.200 & 9870.33600 & -0.012954015 \\
\hline
\end{tabular}

\section{Current Land Circulation Models and Model Innovation}

\section{Traditional Models and Problems}

Rural land circulation is accelerated in recent years, and the circulation market is becoming more perfect. It is estimated that about more than $10 \%$ of the total contracted land area has been transferred in various forms nationwide. The transferred land area can amount to $30 \%$ in some counties of developed areas. But as a whole, it is not enough and there is big room for development.

The present models of land circulation include subcontract, rent-out, double replacement shareholding and assignment. Subcontracting means that some contracted households who can not operate but do not want to give up their land transfer their land use right to others temporarily, upon compensation or free of charge. The land contracted relationship remains unchanged. Renting-out means land contracted households rent out their land use for various reasons based on rent income. Replacement refers to land exchange for the convenience of cultivation and management between two or more land owners, where contracted relationship may or may not change. Assignment takes place between the contracted households who keeps a steady non-agricultural income and is ready to give up the contracted land use rights as well as liabilities and the third party. In this case, the former contracted relationship is replaced and terminated. Shareholding is an advanced circulation form in which the contracted land rights are quantified into stock rights, and the households are incorporated and share dividends according to their stocks. Chongqing, Chengdu, Tianjin, Shenzhen, Jiaxing in Zhejiang province and Shaxian in Fujian province have made pilot practices and gained some experience.

As is seen, land circulation forms mentioned above usually take place between households out of their individual decisions, which can hardly produce circulation scale for lack of information network and is prone to cause chaos and disorder. Disorganized land circulation will pose a negative force in upgrading of agricultural industry. In practice, many land circulations are conducted by oral consensus and agreements, with no written contracts or authoritative intermediary organizations. This may reduce the stability of contracted rights, increase negotiation cost and more easily give rise to disputes. 


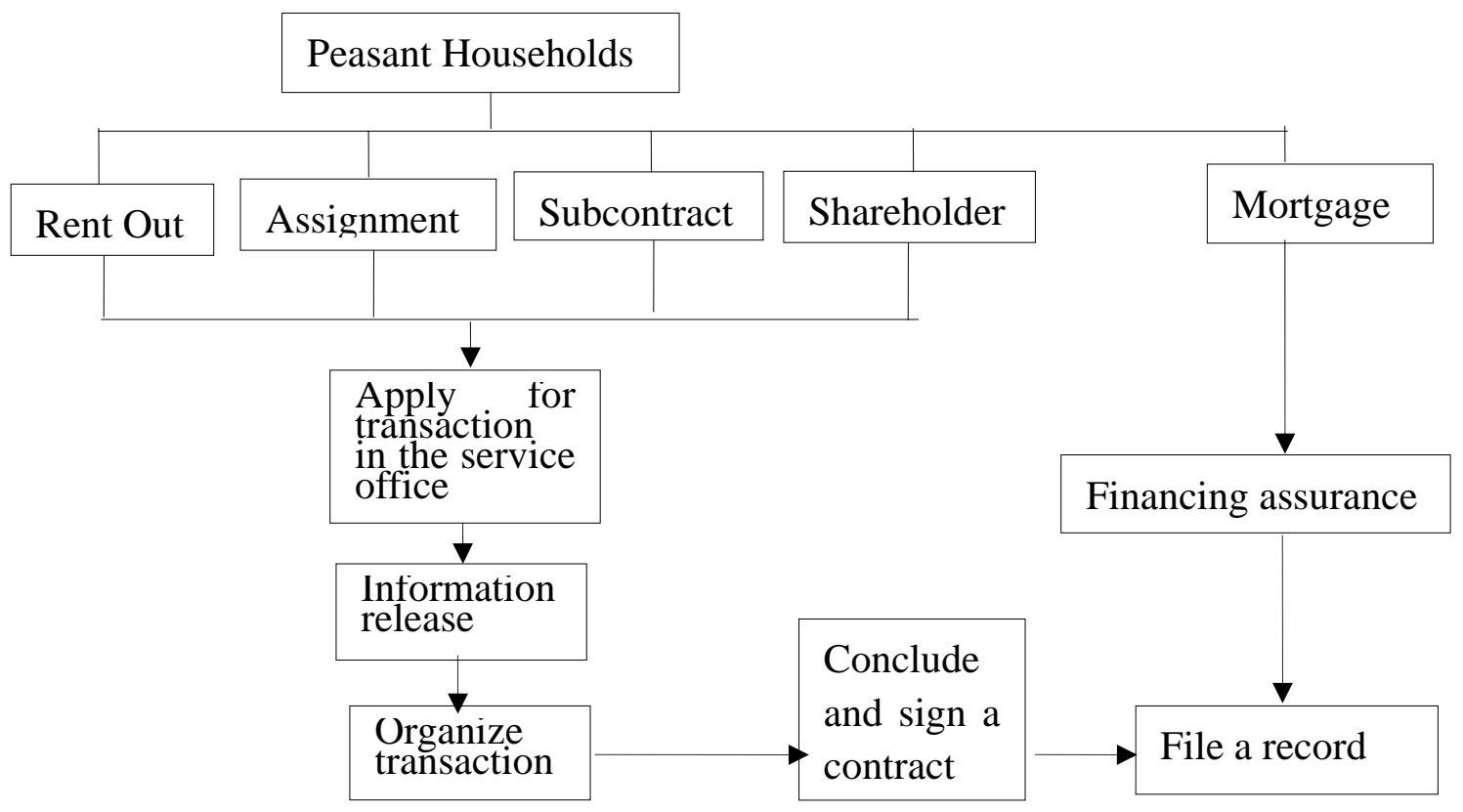

Fig. 3: Process of rural land circulation

\section{Land Circulation Trust - Model Innovation}

Different from unprompted land circulation based on individual decision, land circulation trust is a typical innovation model, in which the government sets up land circulation centers, the township injects capital and establishes land trust corporation. The main responsibility of the trust corporation is to take in the transferred land from peasants and sign trust contracts, and then lease the land to farming enterprises or big households for agricultural development and operation. The trust corporation collects service commissions per mu per year from tenant companies to keep its operation, and the land rent fee will be paid to peasants twice a year.

The model of land circulation trust varies from the other models due to the participation of government, which concludes three advantages. Firstly, the land use right does not change fundamentally and can well evade the peasants risk of losing land. Secondly, peasants can increase their income by sharing dividant. Thirdly, idle land is reduced and scale production is realized.

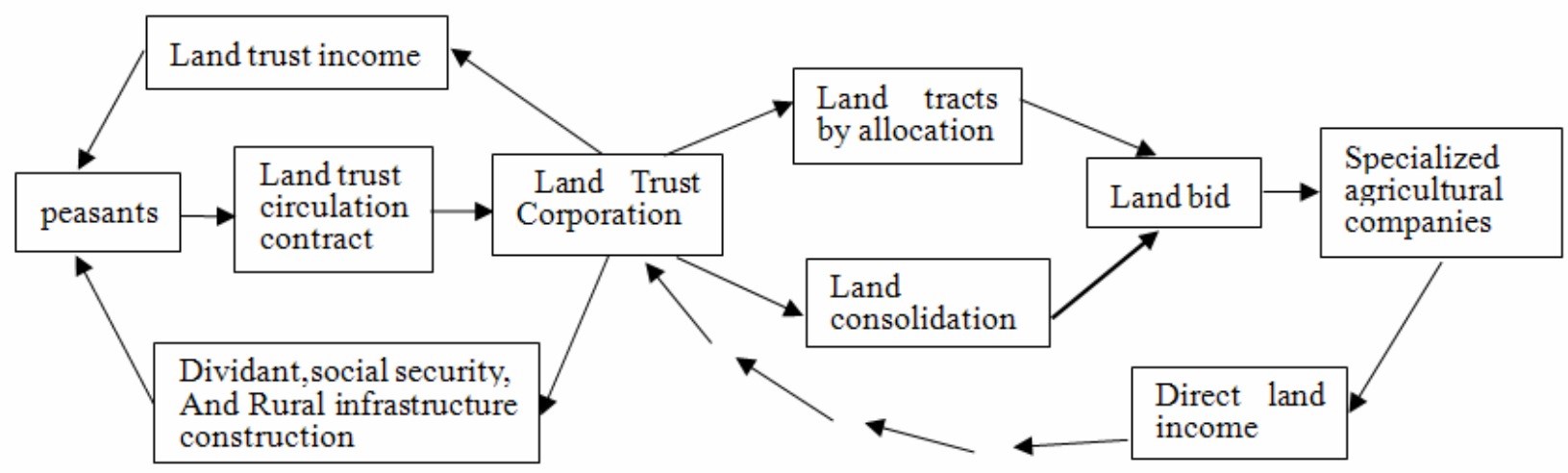

Fig. 4: Land circulation trust procedure 


\section{Government Accountability in Land Circulation Reform}

Property Law of PRC took effect in 2007. It fully confirms the property attribute of contractual right of land, endows peasants with long term and guaranteed land use rights. According to the provisions, the persons with the right to contracted management shall have the right to subcontract, assignment, replacement and son on, which generates a market of land demand and supply, but land circulation may still be hampered as a result of asymmetrical information and unequal status of the dealers. So governments at all levels have to take a part in the process one way or the other.

When peasants enjoy the possession of the property right of land use, they shall have the rights to transfer, right to earnings and right to mortgage in the legal sense. The actual enjoyment of these rights needs some supporting system.

\section{Establishment of Transaction Network}

As part of the supporting system, the establishment of hierarchical presence of transaction network can realize the rights of the peasants and reduce risks incurred by private deals. The land transaction service centers in the village, service offices in the towns, and service branches in the county should be integrated and equipped with LED screens and modern office facilities. At the same time, systems of service commitments, information collection and release, property right evaluation and registration, and dispute mediation and settlement. The presence of transaction market and platform supported by governments can make up for the market failures.

\section{Develop Rural Land Cooperatives}

Rural land cooperative is a kind of specialized peasants cooperation. It has special meanings. First, as far as our land resource endowment is concerned, the practice of big farms as found in Europe and the United States is improper. In practice, we adopt a model of regional distribution and planned farming, which may result in high production cost and poor competitive edge due to decentralized operation and independent accounting. Establishment of rural land cooperatives can solve the problem of small production and big market and gain scale effect. Secondly, the establishment of rural land cooperatives can integrate property resources and solve capital problem for further development. Cooperatives can concentrate the land shares, mortgage to the bank and get the loans, thus directing the capital flow from the urban to the rural areas. Thirdly, Cooperatives can connect both production bases and households as well as leading enterprises or domestic and overseas markets, and promote the status of peasants in the market economy. Peasants can increase their income by industrialized operation, value-added manufacture and enterprise returns. The application of high-tech and advanced mechanic equipment in cooperatives as well as management improvement can promote agricultural production capacity and comprehensive production force fundamentally.

\section{Conclusion}

Land has been playing a very special role in history. Up to now, land is still considered the most important basic means of livelihood and the main sources of income by the peasants. Land circulation reform can not be successful without the participation of government. Government role is also reflected in the supply of basic public services, such as employment training, medical insurance, social security and so on. If there is not a sound social protecting system, peasants can not have the sense of safety because of their poor employment ability and weak anti-risk capability, and they will be less likely to circulate their land, which is detrimental to land circulation reform 
and the development of rural land market. Therefore, land circulation reform and model innovation can never be a single issue but a comprehensive and systematic project.

\section{Acknowledgement}

This research is financially supported by China Scholarship Council under Grant No.CSC201208430349, Hunan Social Science Foundation under Grant No. 11YYB328 and Innovation Platform Item of Universities of Hunan Province under Grant No. 11K058. Special thanks are offered to the library and the Office of the East Asia Initiatives of AUM,USA.

\section{References}

[1] Zuhui Hang, Peng Wang, Rural land circulation: current situation, problems and countermeasures, J. Journal of Zhejiang University (Humani ties and Social Sciences). (2008) pp38-47.

[2] Xiangyuan Meng, Effect of rural land circulation based on urbanization, Urban Issues, (2012) pp68-72.

[3] Xiaohong Lan, Rural land transfer: cause, problem and solutions, Special Zone Economic, (2010) pp. 59-60.

[4] Jiafeng Ma, Social security for peasants in rural land transfer, Journal of Harmonious Society (2009) pp109-110. 